Diabetologia 9, 461-466 (1973)

(C) by Springer-Verlag 1973

\title{
2, 3-Diphosphoglycerate Fluctuations in Erythrocytes Reflecting Pronounced Blood Glucose Variation
}

\author{
In-vivo and in-vitro Studies in Normal, Diabetic and Hypoglycaemic Subjects
}

\author{
E. Standl and H. J. Kolb \\ Diabetes Research Unit and 3rd Medical Department, City Hospital Schwabing, München, Germany (FRG) \\ Received: February 23, 1973, and in revised form: July 9, 1973
}

Summary. No significant differences were found in the erythrocyte 2.3-DPG concentration between 14 normals $(16.82+0.66 \mu$ moles $2.3-\mathrm{DPG} / \mathrm{g} \mathrm{Hb})$ and 44 diabetic patients $(16.22 \pm 0.38$ umoles 2.3-DPG/g $\mathrm{Hb})$. However, in diabetic patients we could demonstrate significant fluctuations determined by the metabolic control of their diabetes. Hyperglycaemic patients $(n=$ 10) developed during treatment, concomitant with declining blood glucose, a significant decrease to $13.97 \pm$ $0.64 \mu$ moles 2.3-DPG/g Hb. After normalization of blood glucose the 2.3-DPG level rose again. Two patients with islet cell tumors had a fluctuation in the 2.3-DPG concentration of about $20 \%$, when symptomatic hypoglycaemia occurred during an extended fast. This variation in 2.3-DPG dependent upon changes in blood glucose was also demonstrated in-vitro by a dialysis technique where glucose was kept constant at 400 or $80 \mathrm{mg} / 100 \mathrm{ml}$. Incubating hyperglycaemic blood $(n=6)$ of uncontrolled diabeties in a high glucose medium, 2.3-DPG was constant over $7 \mathrm{~h}$, whereas at low glucose concentration. 2.3-DPG dropped significantly $(p<0.001)$. Blood from nondiabetic subjects did not show this phenomenon. In-vitro additions of insulin and tolbutamide failed to produce an effect on 2.3-DPG. Our results suggest that pronounced fluctuations of blood glucose in diabetics influence 2.3-DPG levels in erythrocytes and thus might impair peripheral oxygen supply.

Key words: Erythrocyte 2.3-DPG, diabetes, blood glucose variation, islet cell tumor, insulin, tolbutamide, microangiopathy.
Prolonged tissue hypoxia has long been suspected to participate in the development of diabetic microangiopathy $[1,2]$. Ditzel [3] has built up the concept of functional microangiopathy as an early event in diabetic vascular disease. He concluded that variations of tissue oxygen and carbon dioxide tensions play an important role in this disease. Benesch and Benesch [4] and Chanutin and Curnish [5] have shown the importance of 2.3-DPG ${ }^{1}$ on the binding affinity of oxygen to haemoglobin in erythrocytes. 2.3-DPG was found to facilitate oxygen release from red blood cells. Since then a widespread interest has arisen in studying the regulatory mechanism of 2.3-DPG synthesis and breakdown in erythrocytes. Several clinical conditions like anaemia [6], acidosis $[7,8,9]$ and cardiac disease [10] have been detected, where changes in the 2.3-DPG level of the red blood cell occur. In two communications $[11,12]$ we have presented preliminary results on the decrease of 2.3-DPG in diabetics in association with a drop in blood glucose. The purpose of this study was to investigate in-vivo and in-vitro the role of blood glucose on the 2.3-DPG level in normals, diabetics and patients with an islet cell tumor and also the in-vitro effects of insulin and tolbutamide.

1 Abbreviations used: 2.3-DPG $=2.3$-Diphosphogly cerate; $\mathrm{Hb}=$ Haemoglobin; $\mathrm{ATP}=$ Adenosine triphosphate; NADH $=\beta$-Diphosphopyridin Nucleotide reduced; Tris $=$ Tris (hydroxy methyl) aminomethane; EDTA = Ethylendiamine tetraacetic acid

\section{Patients and Methods}

\section{In-vivo Studies}

34 diabetics admitted to hospital and 14 normal subjects (Group I) proven to be nondiabetic by means of a glucose tolerance test were studied. None of the patients was acidotic or suffered from anaemia. Patients with cardiac failure, respiratory or renal insufficiency were not included. The ages varied from 22 to 64 years in the diabetics and from 25 to 60 in the normal controls. 21 diabetics had insulin dependent diabetes and 13 were on oral agents. There was a group of 10 diabetics who had been considerably hyperglycaemic (blood glucose about $300-350 \mathrm{mg} / 100 \mathrm{ml}$ ) yet non-acidotic over a period of more than a week (Group II). At the time of blood sampling for 2.3-DPG measurements the blood glucose concentration was $312 \pm$ $17 \mathrm{mg} / 100 \mathrm{ml} \pm$ S.E.M. These patients were restudied when their blood glucose was normal (Group III). Another group was examined after they had been in good control for more than a week (Group IV). A fifth group consisted of 11 metabolically well-balanced diabeties with microangiopathy proven by ophthalmoscopy. Venous blood was drawn anaerobically into heparinized syringes in the morning after breakfast, the patients being on their usual antidiabetic regimen.

In addition, two patients were studied who were suspected to have an islet cell tumor. While the patients were fasted overnight, blood was collected at short intervals until symptomatic hypoglycaemia occurred and the procedure was finished by the adminis- 
tration of carbohydrates. In both cases an islet cell tumor was found subsequently at surgery.

An aliquot of each blood sample was immediately assayed in a blood gas analyser (Corning-EEL Model 165) for $\mathrm{pH}$, standard bicarbonate and $\mathrm{p} \mathrm{CO}_{2}$.

\section{In-vitro Studies}

Blood was collected as described except EDTA was used as an anticoagulant. Blood aliquots of each individual (about $10 \mathrm{ml}$ ) were placed in a dialysis tube which had previously been soaked in water and tied round a plastic tube to keep the top of the dialysis tubing open during dialysis. The dialysis bag was then placed in a $500 \mathrm{ml}$ Erlenmeyer flask and dialysed against 50 volumes of an isotonic solution containing $8 \mathrm{~g}$ sodium chloride, $0.4 \mathrm{~g}$ potassium chloride and $0.35 \mathrm{~g}$ sodium bicarbonate per liter. The $\mathrm{pH}$ was adjusted at 7.4 by gasing the solution with a mixture of $5 \%$ carbon dioxide in oxygen. The Erlenmeyer flask was incubated in a shaking $37^{\circ}$ waterbath. Since the dialysis bag remained open blood samples could easily be withdrawn by a syringe. The actual glucose concentration of the blood sample in the dialysis bag was kept constant at the desired level by the glucose concentration in the dialysate. Within 30 min the blood glucose level in markedly hyperglycaemic diabetics $(300-400 \mathrm{mg} /$ $100 \mathrm{ml}$ ) dropped to about $80 \mathrm{mg} / 100 \mathrm{ml}$, when dialysed against this glucose concentration, thus imitating clinical improvement of diabetes in vitro. For experiments at high glucose $(400 \mathrm{mg} / 100 \mathrm{ml})$ an aliquot of concentrated glucose solution was added to the blood and dialysed against the dialysate containing $400 \mathrm{mg} /$ $100 \mathrm{ml}$ glucose.

During the dialysis the oxygen pressure $\left(\mathrm{p} \mathrm{O}_{2}\right)$ was kept constantly above 100 torr as measured with a calibrated oxygen electrode (A 3 Potentiograph Eschweiler, Kiel). The $\mathrm{pH}$ of the blood remained unchanged at 7.4. It was an advantage of the dialysis system, that in the dialysis bag the initial blood lactate concentration of about $1 \mathrm{mM}$ did not increase (actually it decreased by about 20 to $30 \%$ ), although there was continuous lactate production (as indicated by a gradual increase of the lactate concentration up to 0.25 $\mathrm{mM}$ in the dialysate).

For studies in the presence of insulin the dialysis system was disadvantageous. Insulin was mixed with a tracer amount of ${ }^{125}$ iodine labelled insulin and added to the incubates at a final concentration of $500 \mu \mathrm{U} / \mathrm{ml}$. As shown by Brodal [13] only intact insulin is precipitated by $5 \%$ trichloroacetic acid, whereas the degradation products of insulin remain in the supernatant. These tests with $\mathrm{I}^{\mathbf{1 2 5}}$-insulin revealed, that after $30 \mathrm{~min}$ of incubation about $80 \%$ of the radioiodine counts were in the dialysate due to dialysis and degradation. Similar results were obtained with native insulin, determined by radioimmunoassay as described by Herbert [14].

Therefore another in-vitro system was set up for these studies. The blood was simply diluted in four volumes of isotonic $0.02 \mathrm{M}$ Tris buffer, containing sodium chloride and potassium chloride, final $\mathrm{pH} 7.4$ and incubated in a $37^{\circ}$ shaking waterbath. Under these conditions we could demonstrate, that after six hours of incubation the insulin concentration was still above $50 \%$ of the initial value. To this system glucose was added to get a final concentration of 80 or $400 \mathrm{mg} /$ $100 \mathrm{ml}$. Again $\mathrm{pH}$ and $\mathrm{p} \mathrm{O}_{2}$ remained constant while the lactate concentration increased continuously from 0.2 to $1 \mathrm{mM}$ during incubation.

Plasma glucose was measured by the Technikon Auto Analyser [15] and haemoglobin by the cyanhaemoglobin method [16]. For the estimation of 2.3DPG and ATP blood was deproteinized in 4 volumes of $5 \%(\mathrm{~W} / \mathrm{V})$ trichloroacetic acid under stirring and centrifuged for $5 \mathrm{~min}$ at $4000 \mathrm{~g}$ at room temperature. The clear supernatant of two extractions, containing more than $95 \%$ of $2.3-\mathrm{DPG}$ of the red cell, were pooled and further diluted with 9 volumes of $0.2 \mathrm{M}$ Tris buffer pH 7.4 to neutralize the sample. 2.3-DPG was determined enzymatically as described by Nygaard (17). Chemicals and enzymes for the test were purchased from Calbiochem (Cat. No. 869237). In this assay the catalytic effect of 2.3-DPG on the reaction rate of phosphoglucomutase coupled with enolase, pyruvate kinase and lactate dehydrogenase results in a decrease of NADH, which was followed with an Eppendorf photometer at $334 \mathrm{~m} \mu$. The accuracy and reproducibility of the 2.3-DPG assay was about $\pm 3 \%$. ATP was evaluated by a modified method of Lamprecht and Trautschold [18], after the trichloroacetic acid supernatant had been extracted three times with ether. Since both enzymatic tests require a number of auxiliary enzymes, standards were carried out at the beginning and the end of a series of experiments. Lactate was determined as described by Hohorst [19]. Porcine crystalline insulin and tolbutamide were a gift of Farbwerke Hoechst, West-Germany.

\section{Results}

Assays with blood of normal test persons (Group I, Table 1) showed a mean 2.3-DPG level of $16.82 \pm 0.66$ umoles per gram haemoglobin. In normals red cell 2.3-DPG content was found to be constant. Five normal subjects were studied repeatedly over months and were also examined on one day at least six times, before and after meals. The 2.3-DPG concentration did not vary more than $\pm 5 \%$.

Diabetes did not effect the 2.3-DPG level in general, as seen in Table 1. As long as the metabolic pattern of the diabetes was stable - regardless whether well or poorly controlled - the 2.3-DPG level did not differ significantly from the normal values. The group of 10 permanent hyperglycaemic, non-acidotic diabetica (Group II) showed the same 2.3-DPG concentration as did group IV consisting of 13 other diabetics, who were well controlled at least one week before being studied. Table 1 also demonstrates that the haemo- 
globin concentration of blood (except group $V$ ) as well as the amounts of ATP per gram haemoglobin remained constant in all these patients. There was, however, a significant fluctuation in the 2.3-DPG level when the metabolic state of diabetes changed. Group II which represents 10 hyperglycaemic, non-acidotic diabetics, who had normal 2.3-DPG values before hospital treatment, showed a significant decrease in 2.3-DPG when restudied after normalization of blood the drop of blood glucose there was a gradual fall in 2.3-DPG concentration. After several days a minimum value of about 13 umoles 2.3-DPG per gram haemoglobin was reached and then 2.3-DPG concentration rose again to the original value. This decrease in the 2.3-DPG concentration in association with changes in blood glucose was significant in comparison to normal subjects as well as to stable well-controlled diabetics (p-values in Table 1).

Table 1. Erythrocyte 2.3-DPG and ATP content of normal subjects and selected groups of diabetics. Details of the groups are given in the Methods section

\begin{tabular}{|c|c|c|c|c|c|c|c|c|}
\hline Group & $\mathbf{n}$ & & $\begin{array}{l}\text { Blood glucose } \\
\mathrm{mg} / 100 \mathrm{ml}\end{array}$ & $\begin{array}{l}\mathrm{Hb} \\
\mathrm{g} / 100 \mathrm{ml}\end{array}$ & $\begin{array}{l}\mathrm{ATP} \\
\mu \text { moles/g Hb }\end{array}$ & $\begin{array}{l}\text { 2.3-DPG } \\
\mu \text { moles/g Hb }\end{array}$ & $\mathrm{pH}$ & $p^{b}$ \\
\hline $\mathrm{I}$ & 14 & normal & $109 \pm 5$ & $15.4 \pm 0.3$ & $3.27 \pm 0.11$ & $16.82 \pm 0.66$ & $7.36 \pm 0.01$ & $<0.01$ \\
\hline II & 10 & diab. & $312 \pm 17$ & $15.1 \pm 0.3$ & $3.52 \pm 0.38$ & $16.22 \pm 0.55$ & $7.37 \pm 0.01$ & $<0.001$ \\
\hline III & 10 & diab. & $148 \pm 7$ & $15.6 \pm 0.4$ & $3.12 \pm 0.34$ & $13.97 \pm 0.64$ & $7.37 \pm 0.01$ & \\
\hline IV & 13 & diab. & $153 \pm 9$ & $15.1 \pm 0.4$ & $3.36 \pm 0.17$ & $16.37 \pm 0.72$ & $7.37 \pm 0.01$ & $<0.01$ \\
\hline $\mathrm{V}$ & 11 & diab. ${ }^{a}$ & $142 \pm 6$ & $14.0 \pm 0.4$ & $3.61 \pm 0.38$ & $17.68 \pm 0.60$ & $7.37 \pm 0.01$ & $<0.005$ \\
\hline
\end{tabular}

values are given as $\overline{\mathrm{x}} \pm$ S.E.M.

a diabeties with retinopathy

${ }^{\mathrm{b}} \mathrm{p}$ values in comparison to group III

Table 2. Blood glucose, pH, haemoglobin and 2.3-DPG of 10 diabetics, initially hyperglycaemic (Group II) and after normalization of blood glucose (Group III)

\begin{tabular}{|c|c|c|c|c|c|c|c|c|}
\hline \multicolumn{5}{|c|}{ Group II } & \multicolumn{4}{|l|}{ Group III } \\
\hline $\begin{array}{l}\text { Subject } \\
\text { number }\end{array}$ & $\begin{array}{l}\text { Blood } \\
\text { gluoose } \\
\mathrm{mg} / 100 \mathrm{ml}\end{array}$ & $\mathrm{pH}$ & $\begin{array}{l}\mathrm{Hb} \\
\mathrm{g} / 100 \mathrm{ml}\end{array}$ & $\begin{array}{l}2.3-\mathrm{DPG} \\
\mu \text { moles/g Hb }\end{array}$ & $\begin{array}{l}\text { Blood } \\
\text { glucose } \\
\mathrm{mg} / 100 \mathrm{ml}\end{array}$ & $\mathrm{pH}$ & $\begin{array}{l}\mathrm{Hb} \\
\mathrm{g} / 100 \mathrm{ml}\end{array}$ & $\begin{array}{l}2.3-\overline{D P G} \\
\mu \text { moles } / \mathrm{g} \mathrm{Hb}\end{array}$ \\
\hline 1 & $\begin{array}{l}359 \\
319\end{array}$ & 7.34 & 14.0 & 13.71 & 132 & 7.37 & 15.7 & 12.36 \\
\hline 2 & $\begin{array}{l}339^{a} \\
340\end{array}$ & 7.38 & 15.7 & 16.56 & $\begin{array}{l}137 \\
177\end{array}$ & 7.37 & 15.7 & 14.78 \\
\hline 3 & $\begin{array}{l}278^{a} \\
239\end{array}$ & 7.37 & 15.7 & 14.56 & $\begin{array}{c}92^{\mathrm{a}} \\
151^{-}\end{array}$ & 7.37 & 17.4 & 11.39 \\
\hline 4 & $\begin{array}{l}249^{\mathrm{a}} \\
336\end{array}$ & 7.40 & 14.6 & 17.80 & $\begin{array}{l}131^{\mathrm{a}} \\
197^{-}\end{array}$ & 7.36 & 16.8 & 13.22 \\
\hline 5 & $328^{a}$ & 7.39 & 14.1 & 15.80 & $\begin{array}{l}165^{\mathrm{a}} \\
155^{\mathrm{a}}\end{array}$ & 7.37 & 13.2 & 12.22 \\
\hline 6 & $\begin{array}{l}306 \\
263^{\mathrm{a}} \\
\\
415\end{array}$ & 7.32 & 17.2 & 15.55 & $\begin{array}{l}142 \\
157^{a} \\
128^{a} \\
114\end{array}$ & 7.34 & 16.1 & 15.23 \\
\hline 7 & $\begin{array}{l}148^{a} \\
382\end{array}$ & 7.38 & 15.4 & 19.95 & $\begin{array}{l}159^{a} \\
133\end{array}$ & 7.35 & 16.0 & 17.60 \\
\hline 8 & $\begin{array}{l}194^{\mathrm{a}} \\
420\end{array}$ & 7.36 & 15.4 & 14.95 & $126^{\mathrm{a}}$ & 7.35 & 15.4 & 13.25 \\
\hline $\begin{array}{r}9 \\
10\end{array}$ & $\begin{array}{l}380^{a} \\
328\end{array}$ & $\begin{array}{l}7.35 \\
7.40\end{array}$ & $\begin{array}{l}14.3 \\
14.3\end{array}$ & $\begin{array}{l}16.81 \\
16.50\end{array}$ & $\begin{array}{l}235 \\
150\end{array}$ & $\begin{array}{l}7.36 \\
7.41\end{array}$ & $\begin{array}{l}15.0 \\
14.7\end{array}$ & $\begin{array}{l}16.80 \\
12.90\end{array}$ \\
\hline $\begin{array}{l}\text { Mean val } \\
\pm \text { S.E.M }\end{array}$ & $\begin{array}{r}312 \\
17\end{array}$ & $\begin{array}{l}7.37 \\
0.01\end{array}$ & $\begin{array}{r}15.1 \\
0.3\end{array}$ & $\begin{array}{r}16.22 \\
0.55\end{array}$ & $\begin{array}{r}148 \\
7\end{array}$ & $\begin{array}{l}7.37 \\
0.01\end{array}$ & $\begin{array}{r}15.6 \\
0.4\end{array}$ & $\begin{array}{r}13.97 \\
0.64\end{array}$ \\
\hline
\end{tabular}

a Additional blood glucose determinations in the afternoon

sugar (Group III). Table 2 gives the individual values of blood glucose, haemoglobin, 2.3-DPG and $\mathrm{pH}$ of group II and III. In most cases the 2.3-DPG value was considerably lower after normalization of blood sugar, while haemoglobin and $\mathrm{pH}$ were constant.

However, the time at which blood was drawn after normalization of glucose was important, since 2.3-DPG did not remain at the low level. Fig. 1 demonstrates one representative patient of group II. Parallel with
Another group of 11 diabetics (Group V) who already had retinal microangiopathy and were wellcontrolled for some time showed mean 2.3-DPG levels of $17.68 \pm 0.60 \mu$ moles 2.3-DPG per gram of haemoglobin (Table 1). This value is slightly high when compared to normal patients or diabetics without any evidence of angiopathy. However, at the same time we also observed slightly reduced haemoglobin levels of $14 \pm 0.4 \mathrm{~g}$ per $100 \mathrm{ml}$ blood, although none of these 
patients suffered from anaemia. It was intriguing to evaluate the effect of rapid changes of blood glucose during hypoglycaemia on the 2.3-DPG content in red

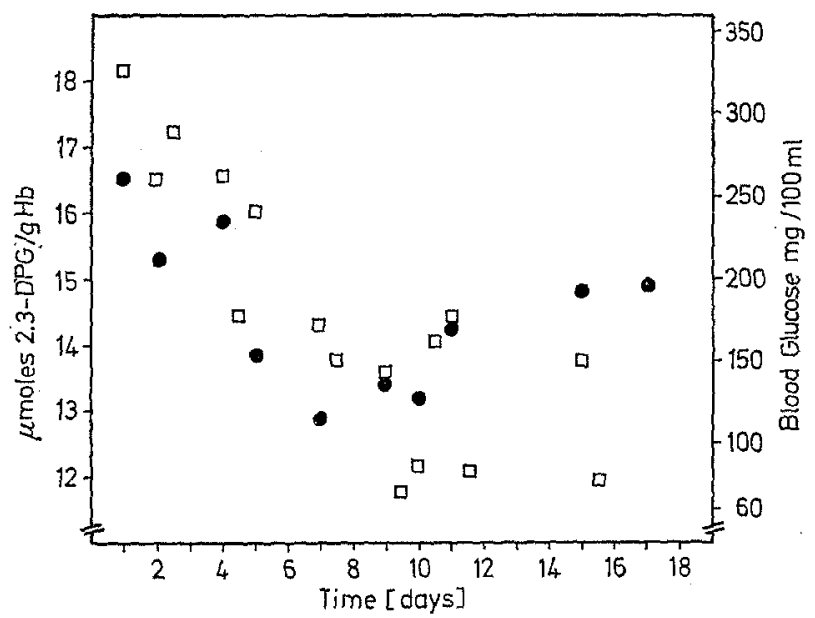

Fig. 1. 2.3-DPG and blood glucose levels of an initially hyperglycaemic diabetic patient during treatment. The filled circles (-) represent the 2.3-DPG, the open squares ([]) the blood glucose concentration

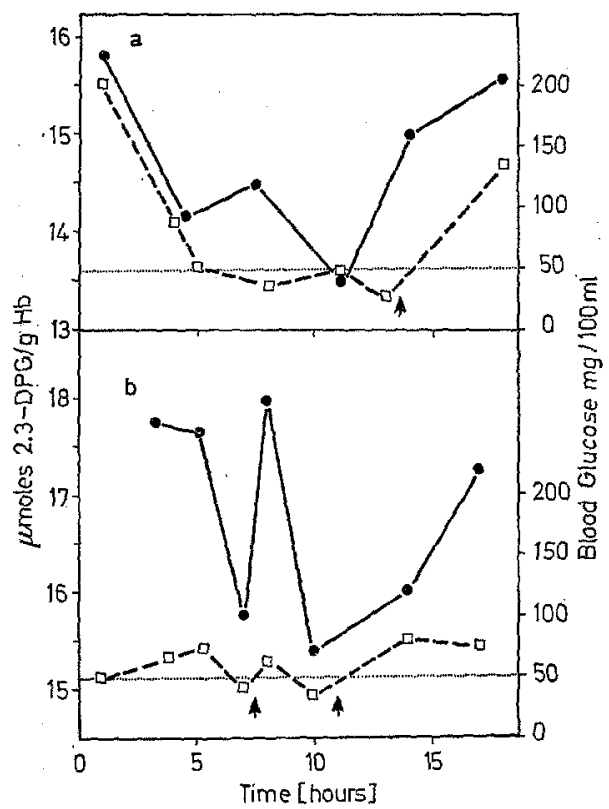

Fig. 2, 2.3-DPG and blood glucose levels of two patients with an islet cell tumor during an extended overnight fast for diagnostic evaluation. Symptomatic hypoglycaemia occurred and carbohydrates were given, as indicated by the arrow. The squares $--\square--\square--$ represent the blood glucose and the filled circles the 2.3-DPG concentration. The dotted line points out the $50 \mathrm{mg} / 100 \mathrm{ml}$ blood glucose level

cells. However, we were not able to investigate diabetics, since pronounced hyperglycaemia before or after insulin reaction prevented a true assessment of the effects of hypogiycaemia. Two patients with spontane- ous hypoglycaemia, who were proven subsequently to suffer from an islet cell tumor were studied instead. These patients developed gradual hypoglycaemia over

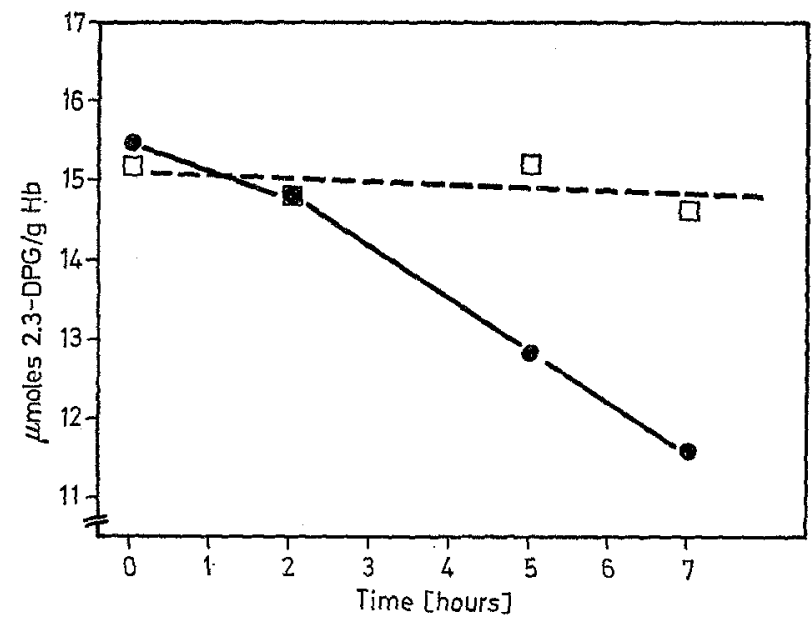

Fig. 3. Mean 2.3-DPG concentration of hyperglycaemic blood from six diabetics incubated in-vitro in the dialysis system at $37^{\circ} .10 \mathrm{ml}$ blood from each patient was dialysed against isotonic buffer $\mathrm{pH} 7.4$ containing $80 \mathrm{mg} / 100 \mathrm{ml}$ ghicose (filled circles - - or $400 \mathrm{mg} / 100 \mathrm{ml}$ glucose (squares $--\square--\square--$ ). The differences at 5 and $7 \mathrm{~h}$ are statistically significant $(p<0.001)$

hours while being on an extended overnight fast. As Fig. 2 indicates, severe hypoglycaemia is also associated with a reduction of red cell 2.3-DPG content of about $20 \%$.

The role of altering blood glucose concentration on the regulation of 2.3-DPG in normal and diabetic subjects was investigated in-vitro using a dialysis technique described in details in 'Methods'. The blood of seven normal subjects incubated and dialysed either against 400 or $80 \mathrm{mg} / 100 \mathrm{ml}$ glucose showed no change in the 2.3-DPG level during the seven hour incubation period. In contrast, blood of six hyperglycaemic nonketotic diabetics behaved differently (Fig. 3). At high glucose concentrations 2.3-DPG was maintained at a constant level (15.08 $\pm 1.02 \mu$ moles $2.3-\mathrm{DPG} / \mathrm{g}$ haemoglobin \pm S.E.M. at the beginning compared to $14.63 \pm$ 0.66 umoles 2.3-DPG/g haemoglobin \pm S.E.M. at the end) whereas at low glucose concentrations 2.3-DPG decreased from an initial value of $15.58+0.75 \mu$ moles 2.3-DPG/g haemoglobin \pm S.E.M. to $12.81 \pm 0.74$ and to $11.58 \pm 0.53 \mu$ moles $2.3-\mathrm{DPG} / \mathrm{g}$ haemoglobin \pm S.E.M. after 5 and 7 hours of incubation (p-values $<0.001)$. Hence, this in-vitro model of clinical improvement of diabetes - as judged by blood glucose revealed a similar phenomenon as did diabetic patients during treatment.

A possible effect of insulin and tolbutamide on the 2.3-DPG concentration of hyperglycaemic blood was investigated in-vitro as described in the 'Methods' section. Blood from three hyperglycaemic diabetics was diluted four times with isotonic Tris buffer, $\mathrm{pH} 7.4$, 
and incubated at either 400 or $80 \mathrm{mg} / 100 \mathrm{ml}$ glucose. Three different sets of experiments have been carried out, i.e. without further addition, in the presence of $500 \mu \mathrm{U}$ insulin $/ \mathrm{ml}$ or $0.1 \mathrm{mg}$ tolbutamide $/ \mathrm{ml}$ incubation volume.

It is noteworthy that the effect of glucose on the 2.3-DPG concentration of hyperglycaemic blood shown in the dialysis experiments, could also be seen with this simple system. No different behavior was observed when insulin or tolbutamide were added. Hence insulin and tolbutamide failed to show an effect on red blood cell 2.3-DPG in this system.

\section{Discussion}

The 2.3-DPG concentration of $16.82 \pm 0.66 \mu \mathrm{moles} / \mathrm{g}$ haemoglobin obtained for normal subjects is in good agreement with values reported in the literature $[8,20$, $21]$. In extension of our previous work $[11,12]$ further evidence was obtained that erythrocytes of diabetics in general contain the same concentration of $2.3-\mathrm{DPG}$ related to haemoglobin as normal nondiabetic subjects. Recently Rörth et al. [22] and Alberti et al. [23] published similar results. In contrast, Ditzel [24] observed a significantly lowered oxygen binding affinity of erythrocytes from diabetics and concluded that diabetics in general might have deereased 2.3-DPG levels. It should be mentioned that Ditzel [24] calculated his oxygen dissociation curves assuming that the $\mathrm{pH}$ was 7.4 in all his diabeties. If the pH was in fact slightly lower, then the curves would have been normal. Our results demonstrate clearly that the metabolic state of the diabetes has to be considered and that there are pronounced differences between diabetic subjects.

A group of markedly hyperglycaemic patients, (mean blood glucose $312 \mathrm{mg} / 100 \mathrm{ml}$ ) with normal 2.3DPG levels before treatment showed a phase with a significantly lowered 2.3-DPG concentration of about $20 \%$ which occurred concomitant with gradual declining blood glucose values due to treatment. After a few days 2.3-DPG rose again to the original concentrations despite persisting low blood glucose values around $140 \mathrm{mg} \%$. A similar phase of sluggish 2.3-DPG increase was observed by Guest and Rapoport [7] and Alberti et al. [25] who found a delayed normalization of 2.3 . DPG in keto-acidotic diabetics although acidosis, which had caused reduced 2.3-DPG levels, had long been corrected.

In-vitro experiments in two different systems, which were carried out with blood from diabetics and normals incubated at high or low glucose concentrations, are in good agreement with our in vivo results. The quick reduction of glucose to about $80 \mathrm{mg} / 100 \mathrm{ml}$ due to dialysis or dilution of blood from hyperglycaemic patients appears to be responsible for the subsequent decrease of 2.3-DPG in erythrocytes during the seven hour incubation period. The same blood sample incubated at $400 \mathrm{mg} / 100 \mathrm{ml}$ glucose or blood of normal subjects did not show this phenomenon. In addition Travis et al. [26] demonstrated that the 2.3-DPG content of normal human red cells incubated two hours with very high glucose concentrations, i.e. $900 \mathrm{mg} /$ $100 \mathrm{ml}$, was somewhat lower compared with incubations at $90 \mathrm{mg} / 100 \mathrm{ml}$ glucose.

Adding a high dose of insulin or tolbutamide to the in-vitro system did not effect the 2.3-DPG concentration in erythrocytes. Therefore it is not likely that the observed decrease in the 2.3-DPG level during treatment is due to administered insulin or tolbutamide. This result is in agreement with recent binding studies by Cuatrecasas [27], who demonstrated that insulin does not interact with human erythrocytes.

Considering the effect of rapid blood glucose changes it was not surprising that diabetics with retinal angiopathy, but being in stable metabolic control for a longer period had quite normal 2.3-DPG levels. The small enhancement of 2.3-DPG values is essentially the result of a slightly reduced haemoglobin concentration in the blood of these patients [6].

It was learnt from the two patients with marked spontancous hypoglycaemia, that the steady-state level of red cell 2.3-DPG is altered not only by a blood glucose drop from high to normal but also from normal to very low.

Our data suggest, that the glycolytic metabolism of the red cell can adapt to different blood sugar levels. A drop in blood glucose is associated with an intermittert reduction of 2.3-DPG, the main energy rich phosphate in erythrocytes. There is no evidence, how that occurs in detail. It could be due to an increased break-down or decreased synthesis of 2.3-DPG or bypassing of the 2.3-DPG step. Since for the last possibility changes in red cell ATP/ADP ratio are relevant, it should be noted, that in all cases the ATP concentration remained constant.

The observed fluctuations in 2.3-DPG concentration of about $20 \%$ in a selected group of diabetics and during hypoglycaemia are of the same order of magnitude as found in other known clinical conditions like anaemia [6]. Theoretically, a decrease in 2.3-DPG of this amount should diminish oxygen release in the peripheral tissue at any given partial pressure of oxygen. Since the 2.3-DPG content is mainly influenced by changes in blood sugar and not by the actual level these data might be pertinent for poorly controlled, unstable diabetics, with frequently varying high and very low blood sugar values. If these observations are a connecting link between metabolic control of diabetes and the known hypoxic changes in early microangiopathy remains still open to question.

Acknowledgements. We are indebted to Professor Dr. H. Mehnert for his interest in this project and for valuable discussions. The skillful technical assistance of Mr. Albert R. Standl is gratefully appreciated. We thank the Deutsche Forschungsgemeinschaft for financial support. 


\section{References}

1. Ashton, N.: Retinal microaneurysm in the nondiabetic subject. Brit. J. Ophthal. 35, 189-212 (1951)

2. Ashton, N., Path, F.C.: Oxygen and the growth and development of retinal vessels. Amer. J. Ophtal. 62, $412-432(1966)$

3. Ditzel, J.: Functional microangiopathy in diabetes mellitus. Diabetes 17, 388 - 397 (1968)

4. Benesch, R., Benesch, R.E.: The effect of organio phosphates from the human erythrocyte on the allosteric properties of hemoglobin. Biochem. biophys. Res. Commun. 26, 162-167 (1967)

5. Chanutin, A., Curnish, R.R.: Effect of organic and inorganic phosphates on the oxygen equilibrium of human erythrocytes. Arch. Biochem. biophys. 121 96-102 (1967)

6. Torrance, J., Jacobs, R., Restrepo, A., Eschbach, J., Lenfant, C., Finch, C.A.: Intraerythrocytic adaption to anemia. New Engl. J. Med. 283, 165-169 (1970)

7. Guest, G.M., Rapoport, S.: Electrolytes of blood plasma and cells in diabetic acidosis and during recovery. J. Proc. Amer. Diab. Ass. 7, 97-115 (1948)

8. Bellingham, A.J., Detter, J.C., Lenfant, C.: Regulatory mechanism of hemoglobin oxygen affinity in acidosis and alkalosis. J. elin. Invest. 50, 700-706 (1971)

9. Astrup, P., Rörth, M., Thorshauge, C.: Dependency on acid-base status of oxyhemoglobin dissociation and 2.3-diphosphoglycerate level in human eryhtrocytes. Scand. J. clin. Lab. Invest. 26, 47-52 (1970)

10. Woodson, R.D., Torrance, J.D., Shappell, S.D., Lenfant, C.: The effect of cardiac disease on hemoglobin-oxygen binding. J. clin. Invest. 49, 1349-1356 (1970)

11. Stand1, E., Kolb, H.: Der Einfluß des Diabetes auf das 2.3-Diphosphoglyzerat in Erythrozyten. 7. Kongress der Deutschen Diabetesgesellschaft, Bad Nauheim 1972

12. Standl, E., Kolb, H., Standl, A., Mehnert, H.: The effect of diabotes on erythrocyte 2.3-diphosphoglycerate. Diabetologia 9, 91 (1973)

13. Brodahl, B.P.: Evidence of an enzymatic degradation of insulin in blood in-vitro. Europ. J. Biochem. 18, 201-206 (1971)

14. Herbert, V., Lau, K.S., Gottlieb, C.W., Bleicher, S.J.: Coated charcoal immunoassay of insulin. J. clin. Endoc. 25, 1375. (1965)
15. Bergmeyer, H.U., Bernt, E., Lachenicht, R.: In: Methoden der enzymatischen Analyse, 2nd ed. H.U. Bergmeyer, (ed.) p. 1181-1185. Weinheim: Verlag Chemie 1970

16. Hallmann, L.: Klinische Chemie und Mikroskopie. 10th ed. p. 591. Stuttgart: Verlag Georg Thieme 1966

17. Nygaard, S.F., Rörth, M.: An enzymatic assay of 2.3-diphosphoglycerate in blood. Scand. J. clin. Lab. Invest. 24, 399-403 (1969)

18. Lamprecht, W., Trautschold, I.: In: Methoden der enzymatischen Analyse, 2nd ed. H.U. Bergmeyer (ed.) p. 2024-2033. Weinheim: Verlag Chemie 1970

19. Hohorst, H.-J.: In: Methoden der enzymatischen Analyse 2nd ed. H.U. Bergmeyer, (ed.) p. 14251429. Weinheim: Verlag Chemie 1970

20. Paniker, N.V., Beutler, E.: Pyruvate effect in maintenance of ATP and 2.3-DPG of stored blood. J. Lab. clin. Med. 78, 472-482 (1971)

21. Beutler, E., Meul, A., Wood, L.A.: Depletion and regeneration of 2.3-diphosglyceric acid in stored red blood cells. Transfusion 9, 109-114 (1969)

22. Alberti, K.G.M.M., Emerson, P.M., Darley, J.H., Hockaday, T.D.R.: Red-cell 2.3-diphosphoglycerate and diabetes. Lancet 1972 I, 843-844

23. Rörth, M., Parving, H.-H., Munkgaard, S.: Red-cell oxygen affinity and 2.3-diphosphoglycerate in diabetes. Lancet. 1972 I, 1179

24. Ditzel, J.: Impaired oxygen release caused by alterations of the metabolism in the erythrocytes in diabetes. Lancet 1972 I, 721-723

25. Alberti, K.G.M.M., Darley, J.H., Emerson, P.M., Hockaday, T.D.R.: 2.3-diphosphoglycerate and tissue oxygenation in uncontrolled diabetes mellitus. Lancet 1972 II, $391-395$

26. Travis, S.F., Morrison, A.D., Clements, Jr., R.S., Winegrad, A.I., Oski, F.A.: Metabolic alterations in the human erythrocyte produced by increases in glucose concentration. The role of the polyol pathway. J. clin. Invest. 50, 2104-2112 (1971)

27. Cuatrecasas, P.: Insulin-receptor interactions in adipose tissue cells. Direct measurements and properties. Proc. nat. Acad. Sci. (Wash.) 68, 1264-1268 (1971)

Dr. Eberhard Standl

Diabetes Research Unit

and 3rd Medical Department

City Hospital Schwabing

D.8000 München 40

Kölner Platz 1

Federal Republic of Germany 